\title{
Pengaruh Penambahan Kapur terhadap Parameter Uji Kuat Geser Batulempung Menggunakan Direct Shear Test
}

\author{
Muhammad Ilham Naufal ${ }^{*}$ \\ Prodi Teknik Pertambangan, Fakultas Teknik, Universitas Islam \\ Bandung, Indonesia. \\ *muhamadilhamn@gmail.com
}

\begin{abstract}
Claystone is a soil composed of weathered solid grains which have low permeability and are very cohesive with high swelling and shrinkage ability that are above the bedrock. In terms of holding the load above it, the claystone must have a stable strength so that it can withstand the settlement due to the load spread along the shear plane. The research methodology used in the implementation of the activity consists of a literature study, preparation of test materials and mixing, data collection on the results of physical and mechanical properties testing and data processing which is then analyzed for the resulting parameters. The research was conducted by mixing slaked lime against claystone at $2 \%, 4 \%, 6 \%, 8 \%, 10 \%$, and $12 \%$ using a waiting time of $3,6,9$, and 12 days. The claystone used in this study has a natural density of $2.03 \mathrm{~g} / \mathrm{cm} 3$, a dry density of $1.7 \mathrm{~g} / \mathrm{cm} 3$ and a natural water content of $19.18 \%$. The optimum value of moisture content obtained in the claystone proctor test is $20.09 \%$ at a maximum dry density of $2.38 \mathrm{gr} / \mathrm{cm} 3 \mathrm{Based}$ on the results of the research carried out, it was found an increase in the test parameters of the material as a result of mixing claystone - Slaked Lime $(\mathrm{Ca}(\mathrm{OH}) 2)$ which resulted in reinforcement in the amount of cohesion (c) and internal friction angle $(\Phi)$ through mixing as much as $6 \%$ in the form of cohesion (c) of 0.15038 $\mathrm{MPa}$ and internal friction angle $(\Phi)$ of $18.5111^{\circ}$ compared to the parameters before mixing the material which obtained cohesion (c) of $0.0523 \mathrm{MPa}$ and internal friction angle $(\Phi) 11.2311^{\circ}$.
\end{abstract}

Keywords: Claystone, Soil Stability, Slaked Lime.

Abstrak. Batulempung merupakan tanah yang tersusun atas susunan butiran padat hasil pelapukan yang memiliki sifat permeabilitas rendah sangat kohesif dengan kemampuan kembang susut yang tinggi yang berada di atas batuan dasar. Dalam hal menahan beban yang berada diatasnya, batulempung harus memiliki kekuatan yang stabil sehingga dapat menahan penurunan akibat adanya pembebanan yang tersebar sepanjang bidang geser. Metodologi penelitian yang digunakan dalam pelaksanaan kegiatan terdiri atas studi literatur, persiapan material uji berikut pencampuran, pengambilan data hasil pengujian sifat fisik dan mekanik serta pengolahan data yang kemudian dilakukan analisis terhadap parameter yang dihasilkan. Penelitian dilakukan dengan melakukan pencampuran kapur padam terhadap batulempung sebesar $2 \%, 4 \%, 6 \%, 8 \%, 10 \%$, dan $12 \%$ dengan menggunakan waktu tunggu pengujian selama $3,6,9$, dan 12 hari. Batulempung yang digunakan dalam penelitian memiliki natural density $2,03 \mathrm{gr} / \mathrm{cm} 3$, dry density $1,7 \mathrm{gr} / \mathrm{cm} 3$ dan natural water content $19,18 \%$. Nilai optimum moisture content yang didapatkan pada pengujian proctor test batulempung sebesar $20,09 \%$ pada kondisi maximum dry density $2,38 \mathrm{gr} / \mathrm{cm} 3$. Berdasarkan hasil penelitian yang dilaksanakan, didapatkan peningkatan parameter uji material hasil pencampuran batulempung - kapur padam $(\mathrm{Ca}(\mathrm{OH}) 2)$ yang menghasilkan perkuatan pada besaran kohesi (c) dan sudut gesek dalam $(\Phi)$ melalui pencampuran sebanyak $6 \%$ berupa kohesi (c) sebesar $0,15038 \mathrm{MPa}$ dan sudut gesek dalam $(\Phi)$ sebesar $18,5111^{\circ}$ dibandingkan parameter sebelum dilakukannya pencampuran material yang mana didapatkan kohesi (c) sebesar 0,0523 MPa dan sudut gesek dalam (Ф) $11,2311^{\circ}$

Kata Kunci: Batulempung, Stabilitas Tanah, Kapur Padam 


\section{A. Pendahuluan}

Batulempung merupakan tanah yang tersusun atas susunan butiran padat hasil pelapukan yang memiliki sifat permeabilitas rendah sangat kohesif dengan kadar kembang susut yang tinggi yang berada di atas batuan dasar. Batulempung memiliki daya dukung yang sangat dipengaruhi oleh mineralogi sebagai hasil dari proses pelapukan batuan (anorganik) maupun material organik. Keberadaan kedua jenis material lapukan tersebut di dalam lapisan tanah sangat mempengaruhi sifat-sifat tanah dalam menerima suatu perilaku.

Dalam hal menahan beban yang berada diatasnya, batulempung harus memiliki kekuatan yang stabil sehingga dapat menahan penurunan akibat adanya pembebanan yang tersebar sepanjang bidang geser. Besarnya daya dukung tanah sangat dipengaruhi oleh nilai kohesi tanah dan sudut gesek dalam tanah tersebut. Pada umumnya tanah memiliki sifat fisik dan mekanik yang terbatas sehingga perilaku yang diberikan akan bergantung pada peruntukannya yang mana dalam perbaikan tanah perlu memperhatikan berbagai faktor salah satunya adalah sifat kembang susut (swelling potential) tanah (Hardiyatmo, 1992).

Perbaikan batulempung sendiri memiliki prinsip dasar dimana kapasitas tanah yang kurang, baik itu dalam berbagai aspek, mengalami peningkatan dan perbaikan melalui sifat-sifat dari pada tanah yang disesuaikan dengan tujuan perbaikan yang diinginkan.

Berdasarkan pemikiran tersebut, maka perlu dilakukannya pengkajian terhadap perbaikan tanah yang dimaksudkan untuk memperbaiki dan/atau mempertahankan kemampuan serta kinerja tanah sesuai syarat teknis yang dibutuhkan, dengan memberikan material sisipan berupa kapur padam ke dalam lapisan tanah tersebut. Selanjutnya, tujuan dalam penelitian ini diuraikan dalam pokok-pokok sebagai berikut.

1. Mendapatkan hubungan antara waktu dan variasi kadar kapur padam (\%) terhadap kadar air tanah;

2. Mendapatkan hubungan antara waktu dan variasi kadar kapur padam (\%) terhadap dry density tanah;

3. Mendapatkan hubungan antara waktu dan variasi kadar kapur padam (\%) terhadap kohesi $\operatorname{tanah}(\mathrm{c})$;

4. Mendapatkan hubungan antara waktu dan variasi kadar kapur padam (\%) terhadap sudut geser dalam tanah $(\phi)$.

\section{B. Metodologi Penelitian}

\section{Penambahan Kapur Padam $\left(\mathrm{Ca}(\mathrm{OH})_{2}\right)$}

Penelitian dimulai dengan tahap persiapan yang merupakan tahap awal untuk menginventarisasi data-data penunjang dan persiapan bahan kapur dan lempung sebagai bahan baku utama. Pengujian sampel meliputi komposisi material penyusun tanah (lempung), menentukan kadar optimum material dan membuat variasi campuran lempung dengan kapur padam.

Data hasil pengujian dikumpulkan berdasarkan komposisi kapur padam dan waktu tunggu hari pengeringan sampel yang selanjutnya dilakukan analisis data menentukan nilai optimal dari masing-masing campuran dan pengujian.

Dengan menggunakan kapur padam $(\mathrm{Ca}(\mathrm{OH}) 2)$ sebagai bahan adiktif dimana terjadinya penambahan bahan kimia tertentu kedalam suatu paduan material tanah sehingga akan menghasilkan reaksi kimia antara tanah dengan bahan yang tercampur padanya yang dapat menghasilkan material baru dengan sifat mekanis yang lebih baik.

Dari pencampuran antara kapur padam dengan material lempung diharapkan akan dapat terjadi suatu reaksi yang membentuk struktur campuran yang stabil yang kemudian dapat meningkatkan nilai parameter dari material lempung uji secara mekanik berupa peningkatan nilai kohesi (c) dan sudut gesek dalam $(\Phi)$ dalam pengujian mekanika tanah yang nantinya akan dapat digunakan sebagai salah satu parameter analisis kestabilan lereng dalam stabilisasi lereng timbunan.

Dalam melakukan pencampuran, kadar kapur padam dibuat dalam beberapa komposisi berbeda yaitu $2 \%, 4 \%, 6 \%, 8 \%, 10 \%$ dan $12 \%$ dari jumlah material lempung yang kemudian akan di uji. Kadar kapur yang digunakan dalam penelitian ini diambil dari total berat material. (Tabel 1) 
Tabel 1. Rekapitulasi Sampel Pengujian

\begin{tabular}{|c|c|c|c|c|c|c|c|c|}
\hline \multirow{2}{*}{ Persentase } & \multicolumn{2}{|c|}{3 Hari } & \multicolumn{2}{|c|}{6 Hari } & \multicolumn{2}{|c|}{9 Hari } & \multicolumn{2}{|c|}{12 Hari } \\
\hline & $\begin{array}{l}\text { Batulempung } \\
\text { (gr) }\end{array}$ & $\begin{array}{l}\text { Kapur Padam } \\
\text { (gr) }\end{array}$ & $\begin{array}{l}\text { Batulempung } \\
\text { (gr) }\end{array}$ & $\begin{array}{c}\text { Kapur Padam } \\
\text { (gr) }\end{array}$ & $\begin{array}{l}\text { Batulempung } \\
\text { (gr) }\end{array}$ & $\begin{array}{c}\text { Kapur Padam } \\
\text { (gr) }\end{array}$ & $\begin{array}{l}\text { Batulempung } \\
\text { (gr) }\end{array}$ & $\begin{array}{l}\text { Kapur Padam } \\
\text { (gr) }\end{array}$ \\
\hline $2 \%$ & 280,15 & 5,60 & 279,47 & 5,59 & 280,83 & 5,62 & 280,19 & 5,60 \\
\hline $4 \%$ & 280,51 & 11,22 & 280,77 & 11,23 & 280,70 & 11,23 & 279,76 & 11,19 \\
\hline $6 \%$ & 279,04 & 16,74 & 279,13 & 16,75 & 280,67 & 16,84 & 279,58 & 16,77 \\
\hline $8 \%$ & 280,25 & 22,42 & 280,17 & 22,41 & 279,79 & 22,38 & 280,93 & 22,47 \\
\hline $10 \%$ & 280,09 & 28,01 & 279,18 & 27,92 & 279,88 & 27,99 & 279,16 & 27,92 \\
\hline $12 \%$ & 280,41 & 33,65 & 279,17 & 33,50 & 280,85 & 33,70 & 279,81 & 33,58 \\
\hline
\end{tabular}

\section{Pengujian Laboratorium}

Pengujian laboratorium yang dilakukan untuk menunjang kegiatan penelitian terdiri atas pengujian sifat fisik tanah, pengujian kepadatan tanah dan pengujian kuat geser langsung tanah.

Pelaksanaan pengujian sifat fisik tanah mengacu pada ASTM D7263-09: Laboratory

Determination of Density (Unit Weight) of Soil Specimens dan ASTM D2216-10: Laboratory Determination of Water (Moisture) Content of Soil and Rock by Mass. Sampel uji yang digunakan dalam pengujian sifat fisik tanah berupa tanah lempung pada kondisi alami serta tanah lempung yang telah mendapatkan penambahan kapur dengan waktu tunggu pengujian.

Sebagai penunjang, dilakukan pengujian kepadatan tanah yang mengacu pada ASTM D698 - 07: Standard Test Methods for Laboratory Compaction Characteristics of Soil Using Standard Effort dan SNI 1742:2008 tentang Cara Uji Kepadatan Ringan untuk Tanah. Sampel yang digunakan dalam pengujian ini berupa tanah lempung pada kondisi alami.

Pelaksanaan pengujian geser tanah sebagai fokus utama penelitian ini mengacu pada SNI 3420:2016 tentang Metode uji kuat geser langsung tanah tidak terkonsolidasi dan tidak terdrainase. Sampel uji yang digunakan dalam pengujian geser langsung tanah berupa tanah lempung pada kondisi alami serta tanah lempung yang telah mendapatkan penambahan kapur $2 \%, 4 \%, 6 \%, 8 \%, 10 \%$ dan $12 \%$ dengan waktu tunggu pengujian 3 Hari, 6 hari, 9 Hari hingga 12 Hari.

Tabel 2. Rekapitulasi Pengujian Kuat Geser Langsung Tanah Kondisi Penambahan Kapur Padam

\begin{tabular}{|c|c|c|c|c|c|c|}
\hline Hari & No. & \multicolumn{3}{|c|}{ Sample Code } & Cohesion (MPa) & Friction Angel $\left(^{\circ}\right)$ \\
\hline 3 & 1 & $2 \%$ & - & 3 Hari & 0,0650 & 11,0287 \\
\hline 6 & 2 & $2 \%$ & - & 6 Hari & 0,1024 & 11,8426 \\
\hline 9 & 3 & $2 \%$ & - & 9 Hari & 0,1250 & 14,6451 \\
\hline 12 & 4 & $2 \%$ & - & 12 Hari & 0,1420 & 15,8972 \\
\hline 3 & 5 & $4 \%$ & - & 3 Hari & 0,0670 & 11,5605 \\
\hline 6 & 6 & $4 \%$ & - & 6 Hari & 0,1110 & 12,2646 \\
\hline 9 & 7 & $4 \%$ & - & 9 Hari & 0,1270 & 16,6109 \\
\hline 12 & 8 & $4 \%$ & - & 12 Hari & 0,1450 & 17,0769 \\
\hline 3 & 9 & $6 \%$ & - & 3 Hari & 0,1050 & 12,1565 \\
\hline 6 & 10 & $6 \%$ & - & 6 Hari & 0,1220 & 15,1466 \\
\hline 9 & 11 & $6 \%$ & - & 9 Hari & 0,1350 & 18,3077 \\
\hline 12 & 12 & $6 \%$ & - & 12 Hari & 0,1500 & 18,5111 \\
\hline 3 & 13 & $8 \%$ & - & 3 Hari & 0,0620 & 14,0345 \\
\hline 6 & 14 & $8 \%$ & - & 6 Hari & 0,0970 & 16,1426 \\
\hline 9 & 15 & $8 \%$ & - & 9 Hari & 0,1120 & 21,1097 \\
\hline 12 & 16 & $8 \%$ & - & 12 Hari & 0,1390 & 21,5993 \\
\hline 3 & 17 & $10 \%$ & - & 3 Hari & 0,0570 & 15,0939 \\
\hline 6 & 18 & $10 \%$ & - & 6 Hari & 0,0790 & 19,0680 \\
\hline 9 & 19 & $10 \%$ & - & 9 Hari & 0,1030 & 23,5236 \\
\hline 12 & 20 & $10 \%$ & - & 12 Hari & 0,1320 & 24,7445 \\
\hline 3 & 21 & $12 \%$ & - & 3 Hari & 0,0550 & 18,1038 \\
\hline 6 & 22 & $12 \%$ & - & 6 Hari & 0,0710 & 21,1097 \\
\hline 9 & 23 & $12 \%$ & - & 9 Hari & 0,0930 & 26,4854 \\
\hline 12 & 24 & $12 \%$ & - & 12 Hari & 0,1310 & 27,0690 \\
\hline
\end{tabular}




\section{Hasil Penelitian dan Pembahasan}

\section{Pengaruh Campuran Terhadap Parameter Kuat Geser}

Gambar 1 menunjukkan bahwa penambahan kapur hingga persentase 6\% akan menghasilkan kenaikan nilai kohesi terbesar hingga mencapai $0,15 \mathrm{MPa}$ untuk waktu tunggu 12 hari yang kemudian akan menyebabkan penurunan nilai kohesi hingga 0,05 MPa.

Kapur yang berperan sebagai bahan aditif memiliki kemampuan untuk mengikat dan menurunkan sensitif batulempung terhadap air. Selain itu, kapur memiliki butiran halus yang menyebabkan mudahnya air terserap karena kepadatan porinya yang rendah. Hal inilah yang dapat menyebabkan sampel uji menjadi lebih padat berikut kapur yang menjadi penyebab berkurangnya kadar air dalam sampel uji.

Disisi lain, terlihat setelah penambahan kapur sebanyak $8 \%$ hingga $12 \%$ menyebabkan penurunan kohesi yang signifikan. Hal ini dapat terjadi karena penambahan kapur yang berlebihan dapat menyebabkan kemampuan daya ikat antar partikel tanah menghilang.

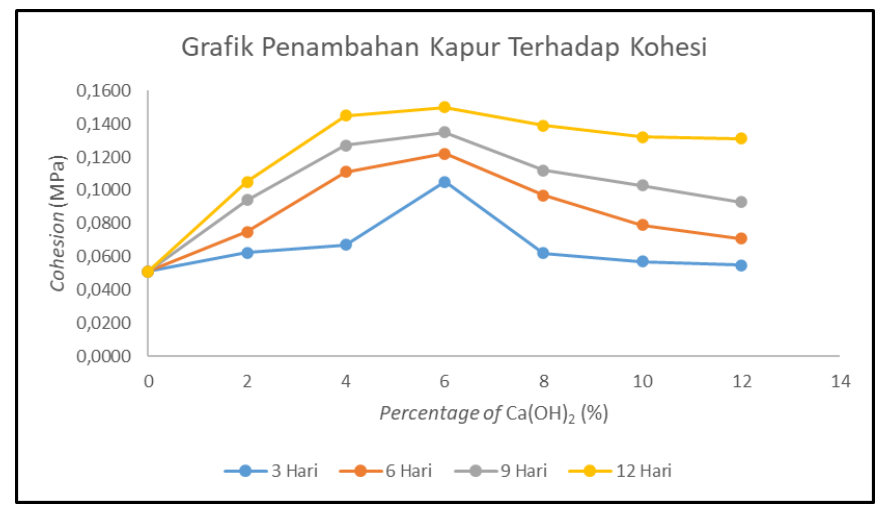

Gambar 1. Grafik Penambahan Kapur Terhadap Kohesi

Dalam pelaksanaan penelitian, waktu tunggu dimaksudkan untuk memberikan jeda waktu sehingga kapur yang ditambahkan kedalam tanah dapat bereaksi. Pada Gambar 2 terlihat bahwa kohesi tanah meningkat seiring dengan semakin lama jeda waktu yang diberikan.

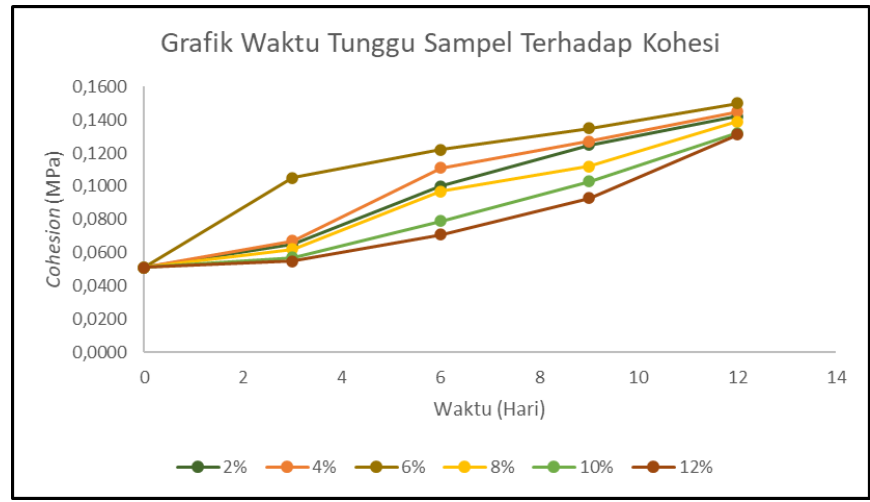

Gambar 2. Grafik Waktu Tunggu Sampel Terhadap Kohesi

Pada Gambar 3 Terlihat bahwa terjadi peningkatan nilai sudut geser $(\phi)$ batulempung karena adanya penambahan kapur yang bervariasi. Nilai tertinggi sudut geser didapatkan pada penambahan kapur dengan persentase $12 \%$ dan jeda waktu selama 12 hari yaitu sebesar $27,0690 \mathrm{o}$. Kondisi lain yang ditunjukan pada grafik adalah nilai terendah perubahan sudut geser pada persentase $2 \%$ dengan jeda waktu selama 3 hari. 


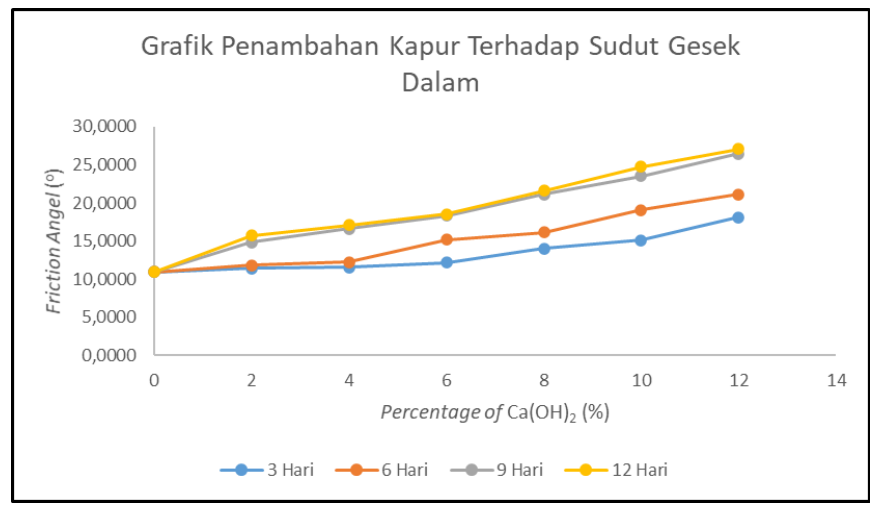

Gambar 3. Grafik Penambahan Kapur Terhadap Sudut Gesek Dalam

Batulempung pada dasarnya memiliki kandungan air alami, kemudian mendapatkan penambahan kapur padam, seiring berjalannya waktu tunggu pengujian, menyebabkan kapur padam yang telah dicampurkan bereaksi dengan air yang terkandung didalam batulempung. Semakin bertambahnya kuantitas kapur padam yang digunakan, semakin cepat pula reaksi yang terjadi akibat bertambahnya agen sementasi, sehingga menyebabkan peningkatan bidang kontak antar butir dalam sampel uji. Sebagai akibat terjadinya peningkatan bidang kontak antar butir dalam batulempung, menyebabkan gaya geser antar butir semakin besar yang berimplikasi pada peningkatan nilai sudut geser.

Gambar 4 memperlihatkan bahwa terjadinya peningkatan sudut geser untuk setiap penambahan kapur dengan nilai tertinggi didapatkan pada penambahan kapur dengan persentase $12 \%$ jeda waktu selama 12 hari, sedangkan nilai terendah untuk perubahan sudut geser didapatkan pada kondisi persentase $2 \%$ dengan jeda waktu selama 3 hari.

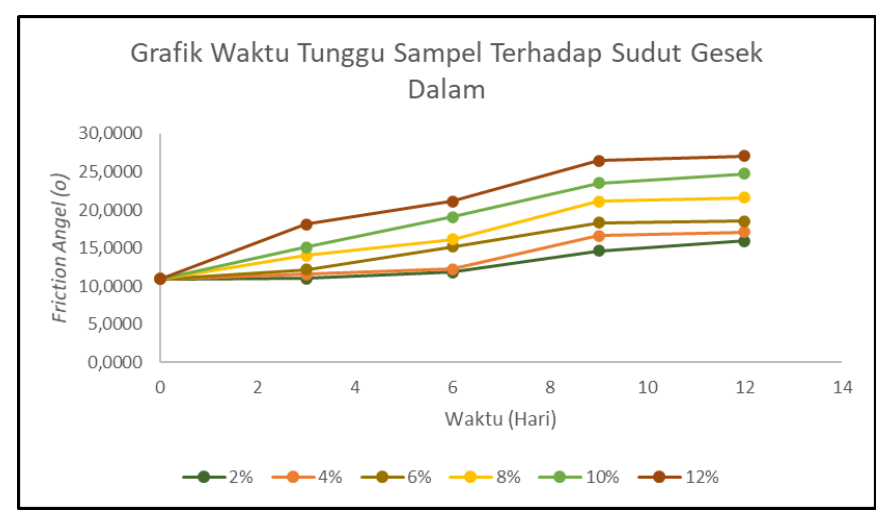

Gambar 4. Grafik Waktu Tunggu Sampel Terhadap Sudut Gesek Dalam

\section{Pengaruh Campuran Kapur Terhadap Parameter Sifat Fisik Tanah}

Berdasarkan hasil penelitian yang dilakukan terhadap batulempung dengan kondisi alami didapatkan kadar air sebesar 19,18\% sedangkan untuk batulempung dengan kondisi penambahan kapur, didapatkan kadar air dengan nilai tertinggi sebesar 21,95\%, yaitu ditemukan pada batulempung dengan penambahan kapur sebanyak 12\% dengan waktu tunggu 12 hari. 


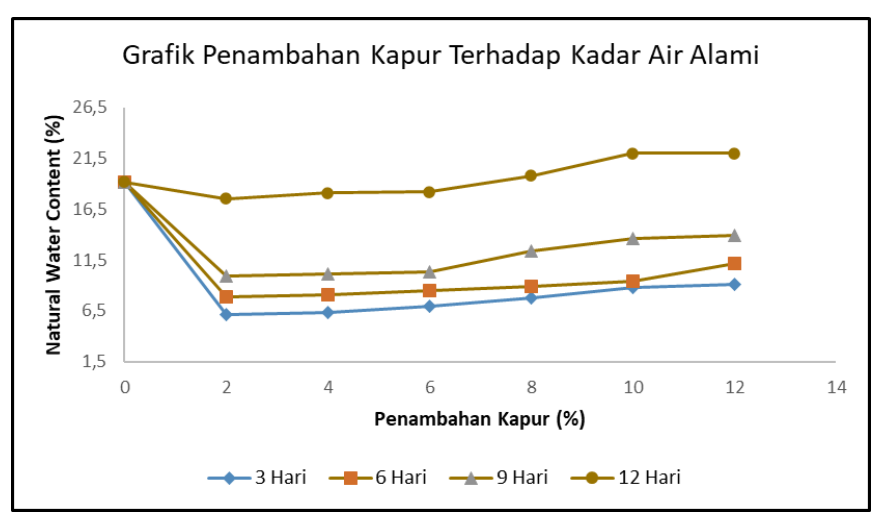

Gambar 5. Grafik Penambahan Kapur Terhadap Kadar Air

Pada kondisi alami, batulempung yang digunakan memiliki massa jenis kering sebesar $1,70 \mathrm{~g} / \mathrm{cm} 3$ sedangkan dalam kondisi penambahan kapur padam, didapatkan nilai massa jenis kering yang bervariasi seiring dengan kuantitas kapur yang ditambahkan serta waktu tunggu pengujian yang digunakan pada sampel uji.

Massa jenis kering terbesar yang didapatkan dalam penelitian yaitu berada pada kondisi penambahan kapur sebanyak $2 \%$ dari total berat sampel uji dengan waktu tunggu selama 3 hari sedangkan massa jenis terendah didapatkan pada kondisi penambahan kapur sebanyak $12 \%$ dengan waktu tunggu selama 12 hari sebesar $1,57 \mathrm{~g} / \mathrm{cm} 3$.

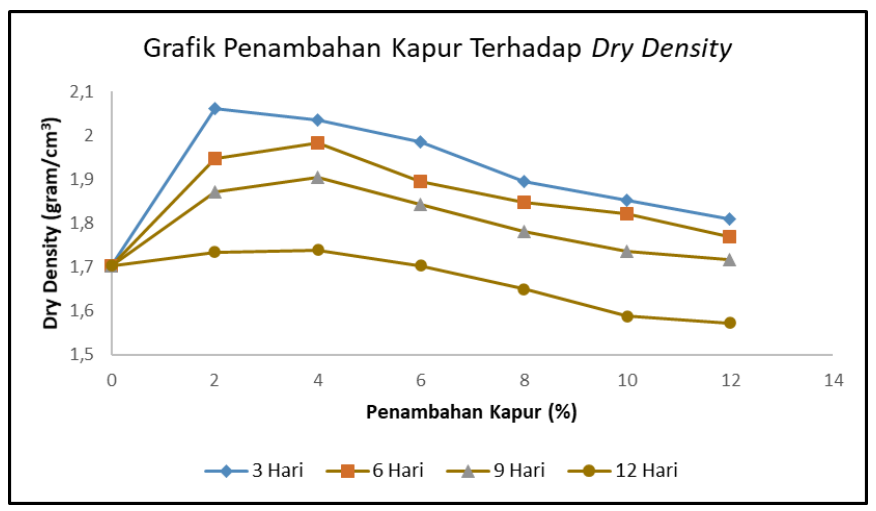

Gambar 6. Grafik Penambahan Kapur Terhadap Massa Jenis Kering

\section{Parameter Uji Pemadatan Tanah}

Berdasarkan penelitian yang dilakukan pada sampel pengujian dengan kondisi alami, didapatkan maksimum dry density sebesar 2,38 gram $/ \mathrm{cm} 3$ pada kondisi penambahan air sebanyak $280 \mathrm{ml}$ dengan nilai rata-rata water content sebesar 17,26\%. Dilakukannya penelitian ini sendiri ditujukan untuk melihat perilaku yang dimunculkan oleh sampel uji pada kondisi penambahan air secara bertahap. 


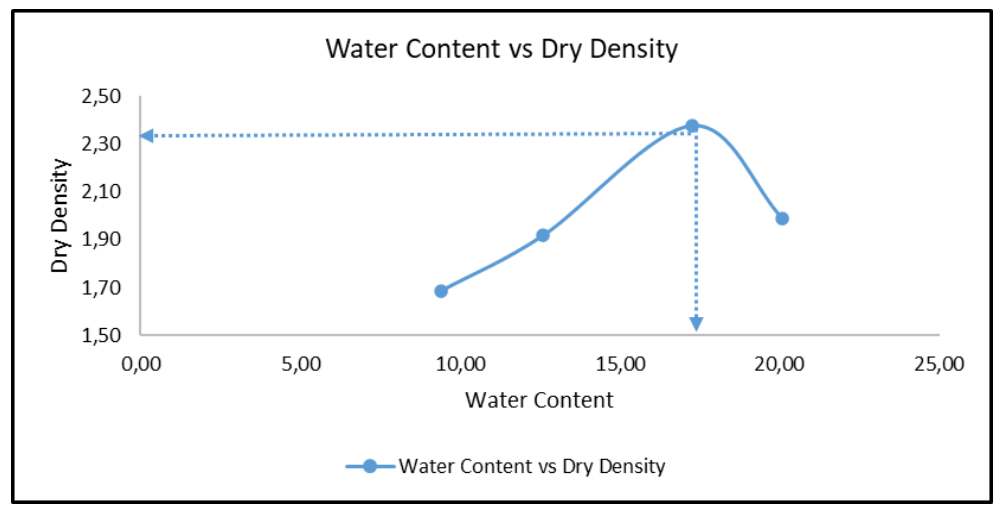

Gambar 7. Grafik Kadar Air Terhadap Massa Jenis Kering

Terlihat bahwa dengan dilakukannya penambahan air pada sampel menyebabkan peningkatan dry density yang dimulai pada saat dilakukannya penambahan $140 \mathrm{ml}$ air hingga sebelum mengalami penurunan nilai yang terjadi pada penambahan $350 \mathrm{ml}$ air.

Muncul satu kondisi dimana terjadi kenaikan dry density seiring meningkatnya water content, kondisi ini timbul sebagai akibat volume udara dalam sampel tanah mencapai titik terendah dan dry density tanah mencapai titik tertinggi. Disaat penambahan air terus dilakukan, Kadar air akan mencapai optimum yang pada penelitian ini berada pada nilai 17,26\% kemudian mengalami penurunan pada saat kadar air mencapai 20,09\%.

Penurunan yang terjadi pada dry density akibat kadar air yang semakin meningkat disebabkan oleh air yang menempati ruang lebih didalam tanah yang muncul karena tidak adanya ruang tersisa sehingga dry density tanah akan mengalami penurunan.

\section{Kesimpulan}

Berdasarkan hasil penelitian, dapat ditarik kesimpulan, yaitu :

1. Hubungan antara waktu dan variasi kadar kapur padam terhadap kadar air pada sampel uji terbentuk dimana semakin banyak kuantitas kapur yang digunakan (\%) menghasilkan peningkatan kadar air yang terlebih dahulu terjadi penurunan dari kondisi alami sampel uji. Kondisi ini muncul sebagai akibat adanya reaksi yang terbentuk pada butiran sampel uji yang menghasilkan banyaknya rongga sehingga memungkinkan air untuk dapat bersarang.

2. Hubungan antara waktu dan variasi kadar kapur padam terhadap dry density pada sampel uji terbentuk dimana semakin banyak kuantitas kapur yang digunakan (\%) menghasilkan penurunan dry density, hal ini muncul sebagai akibat perubahan massa yang terbentuk terhadap volume pada satuan ukuran yang serupa.

3. Hubungan antara waktu dan variasi kadar kapur padam terhadap kohesi pada sampel uji terbentuk dimana semakin banyak kuantitas kapur yang digunakan (\%) menghasilkan peningkatan kohesi hingga penambahan 6\% kapur padam yang diikuti dengan penurunan. Dimana, hal ini muncul sebagai akibat adanya ketidakseragaman butir pada sampel uji.

4. Hubungan antara waktu dan variasi kadar kapur padam terhadap sudut gesek dalam pada sampel uji terbentuk dimana semakin banyak kuantitas kapur yang digunakan (\%) menghasilkan peningkatan nilai sudut gesek dalam. Hal ini terjadi sebagai akibat terjadinya peningkatan bidang kontak antar butir pada batulempung yang digunakan.

\section{Acknowledge}

1. Orang Tua dan Keluarga Penulis, Kedua Orangtua, Efrianto dan Emilinda, terimakasih untuk selalu ada dan senantiasa memberikan dukungan kepada penulis, sungguh tidak ada nikmat lain yang dapat menggantikannya. Kedua adik, Aisyah Qanitah dan Syaira Tria Malika yang selalu menemani, menghibur dan menjadi teman bagi penulis dalam segala waktu.

2. Dosen dan Staff Program Studi Teknik Pertambangan Universitas Islam Bandung. 
kepada Bapak Dr. Ir. Yunus Ashari, M.T. selaku Ketua Prodi, Bapak Noor Fauzi Isniarno, S.Si.,S.Pd., M.T. selaku Sekretaris Prodi, Bapak Ir. Yuliadi, S.T., M.T. selaku Pembimbing yang senantiasa memberikan arahan dalam pengerjaan Skripsi, Bapak Iswandaru, S.T., M.T. selaku Co-Pembimbing yang senantiasa memberikan support dan arahan dalam melakukan penelitian, Bapak Ir. Zaenal, M.T. Selaku Koordinator Skripsi yang senantiasa mengarahkan dalam kelancaran pelaksanaan kegiatan Skripsi, Bapak Dr. Dudi Nasrudin Usman, S.T., M.T. selaku Dosen Wali yang telah banyak membimbing hingga penulis dapat sampai pada waktu ini dan seluruh tenaga pendidik yang tidak dapat disebutkan satu persatu yang menjadi bagian dari kehidupan perkuliahan penulis.

3. Staff Asisten Laboratorium Tambang Unisba, Terimakasih kepada Bapak Ir. Zaenal, M.T. Ibu Elfida Moralista, S.Si., M.T. dan Bapak Iswandaru, S.T., M.T. yang senantiasa hadir sebagai sosok orang tua di Kampus. Bapak Aang Haerudin dan Kang Setia yang senantiasa mengajarkan ilmu baru dan bermanfaat dalam setiap kegiatan. Abang-kakak, teman-teman dan adik-adik sesama Asisten Laboratorium Tambang yang senantiasa mendukung penulis dalam mengerjakan penelitian.

4. Keluarga Besar Tambang 2017, terimakasih karena telah dan selalu menjadi bagian yang tidak pernah hilang dalam kehidupan penulis. Hidup Tambang, Kuat Tambang, Jaya Tambang.

\section{Daftar Pustaka}

[1] Al-Durah, M. a. (1981). New methods of studying soil. Soil Sci.Soc.Am. J.

[2] BS, B. S. (5930:1999). Code of Practice for Site Investigations. London, UK.

[3] Casagrande, A. (1942). Unified Soil \& Clasification System. (USCS).

[4] Darwis, H. (2017). Dasar-Dasar Teknik Perbaikan Tanah. Yogyakarta: Pustaka AQ.

[5] Das, B., Endah, N., \& Indrasurya. (1988). Mekanika Tanah (Prinsip-prinsip Rekayasa Geoteknis) (1st ed.). Jakarta: Erlangga.

[6] Haras, M., E., T. A., \& Legrans, R. R. (2017). Pengaruh Penambahan Kapur Terhadap Kuat Geser Batulempung. TEKNO Vol.15/No.67, 79.

[7] Hatmoko, J. T., \& Lulie, Y. (2007). UCS Batulempung Ekspansif yang Distabilisasi dengan Abu Ampas Tebu dan Kapur. Teknik Sipil, VIII (1), 64-77.

[8] Head, K. H. (1981). Rock Characterization, Testing, and Monitoring. Ed. E.T. Brown. Oxford: ISRM, International Society for RockMechanics.

[9] Ingles, \& Metcalf. (1972). Soil Stabilization Second-Ed.

[10] Kerr. (1959). 15-macam-mineral. Jakarta: PT. Erlangga.

[11] Soedarmo, D., \& Purnomo, E. (1993). Mekanika Tanah. Malang: Kanisius.

[12] Suardi, E. (2005). Kajian Kuat Tekan Bebas Batulempung yang Distabilisasi Dengan Aditive Semen dan Kapur. Jurnal Ilmiah Poli Rekayasa, I (1).

[13] Wyllie, D. C., \& Mah, C. W. (2004). Rock Slope Engineering. New York: Spon Press. 